症例

魚骨の消化管穿通による腹腔内腫瘤の 1 例

国立横浜病院外科

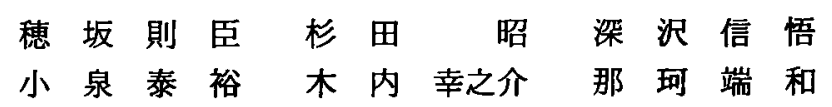

症例は48歳男性で，1994年 8 月，食後に腹痛があり，9月になり腹部腫㿎を自覚した ため近医受診した.腹部 CT 検查て腹腔内腫瘤を指摘され精查目的で当院入院となった。 入院時には湾左側に径 $8 \mathrm{~cm}$ の圧痛を伴う表面平滑, 弾性硬の腫瘤を触知した. 血液検查 では白血球, CRP の上昇を認め, 腹部 CT, 超音波検査では, 腹腔内に笑出する内部不 均一で, 内腔に直線状の石灰化を伴う腫瘤を認め, 腹腔内炎症性腫瘤の診断で開腹術を 施行した。腫瘤は横行結腸に強固に垫着しており大網に被覆され，左腹直筋直下で腹膜 に接していた，摘出した腫瘤は黄白色充実性で一部膿汁を含み，長径 $4 \mathrm{~cm}$ の魚骨と思わ れる異物を認めた。本症例では魚骨が横行結腸を穿通し, 腹腔内に膿瘍を形成したと考 えられた. 原因不明の腹腔内腫瘤では腸管内異物による穿通の可能性も考えて診断, 治 療を行う必要があるといえる。

索引用語：魚骨，消化管穿通，腹腔内腫瘤

\section{緒 言}

誤與された異物の大多数は何ら障害を与えることな く排泄されるが，まれに消化管を穿通して外科的治療 の対象となることがある，消化管穿通の原因となる誤 㗂異物は, 本邦では魚骨がもっとも多く2), その術前診 断はきわめて困難とされてきた. しかし近年の画像診 断の進歩にともない, 術前もしくは術後 retrospective に診断された報告(例が散見されてきだ).われわれは 魚骨の消化管穿通による腹腔内膿瘍の 1 例を経験し, その特徵的な画像所見を検討したので，本邦報告例の 集計をふくめて報告する。

\section{症 例}

患者：48歳，男性。

主訴：腹痛, 腹部腫瘤。

既往歴：特記すべきことなし。

家族歴：特記すべきことなし.

現病歴：平成 6 年 8 月, 食後に腹痛があり，9月に なり腹部腫瘤を認めたため近医で腹部 CT 検査施行, 腹腔内腫㴼を指摘され当院入院となった.

現症：身長 $167.5 \mathrm{~cm}$, 体重 $64 \mathrm{~kg}$ ，栄養状態良好，血 圧 $160 / 100 \mathrm{mmHg}$, 脈拍 $78 /$ 分整, 体温 $37^{\circ} \mathrm{C}$, 眼瞼, 眼

1995年 8 月 8 日受付 1996 年 4 月 12 日採用
球結膜に負血, 黄疸なし. 表在リンパ節は触知しなかっ た。腹部所見では，臍左側に接し径 $8 \mathrm{~cm}$ の表面平滑， 弾性硬の腫瘤を触知した。腫㾿は可動性に乏しく，著 しい压痛をともなうが筇性防御・Blumberg 徵候は認 めなかった，肝・脾は触知せず，腸雑音はえ進してい なかった.

入院時検查所見 : 赤血球 $423 \times 10^{4} / \mathrm{mm}^{3}$, 血色素13.2 $\mathrm{g} / \mathrm{dl}, \mathrm{Ht} 40.5 \%$, 白血球 $13,200 / \mathrm{mm}^{3}$ (Stab $4 \%$, Seg $7 \%$, Baso $0 \%$, Eosio $1 \%$, Mono $4 \%$, Lymph $31 \%)$, 血小板 $39.9 \times 10^{4} / \mathrm{mm}^{3}, \mathrm{CRP} 8.5 \mathrm{mg} / \mathrm{dl}$, 便潜 血 (-), CEA 0.5ng/ml, 肝機能, 腎機能, その他生 化学には異常を認めなかった。

腹部単純 X 線所見：free air, niveau，石灰化等の 異常所見は認められなかった。

注腸所見 : 大腸の狭窄, 壁不整, 陰影欠損や cobblestone appearance などは認められなかった.

腹部超音波検査所見：4 $43 \mathrm{~cm}$ の内部 echo 不均一 な腫瘤を認め, その内腔には直線状の石灰化陰影がみ られた（図 1 ).

腹部 CT 検査所見：左腹直筋直下腹膜, および横行 結腸に接し，内部に low density area を含む腫瘦を認 めた。 また超音波所見と同様に，腫瘤内に直線状の high density areaがみられた（図2）。 


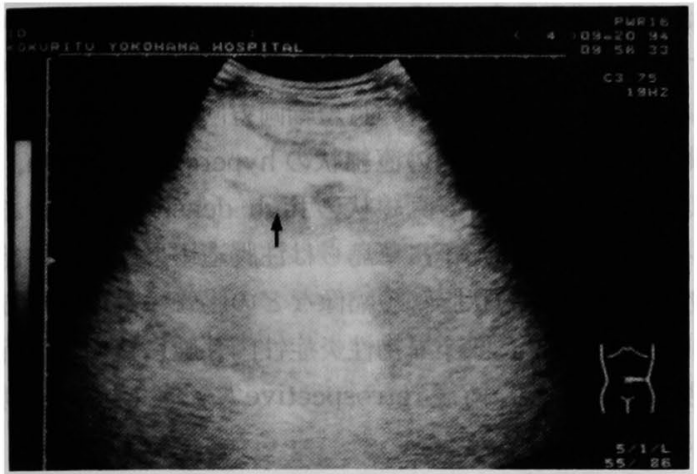

図 1 腹部超音波検査 : 約 $4 \times 3 \mathrm{~cm}$ の内部 echo 不均 一な腫瘤を認め, その内部に直線状の hyperechoic area（†）を認める.

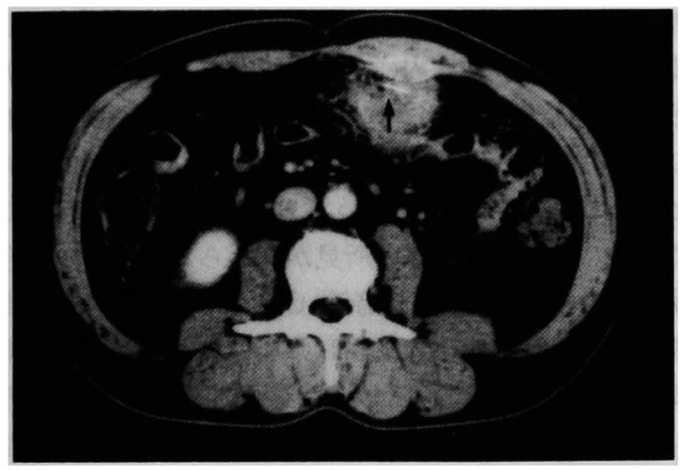

図 2 腹部 CT 検査 : 左腹直笳直下および, 横行結腸 に接して一部 low density area を含む腫瘤を認め, その内部に直線状 high density area（†）を認める.

以上より腹部所見, 検査所見, 画像所見により炎症 性腫瘤と診断, 平成 6 年 9 月 28 日開腹術を施行した.

手術所見：腫瘤は左腹直筋直下で腹膜に接し, 横行 結腸に強固に癒着しており大網に被覆されていた. 腫 瘤を横行結腸から鋭的に切離し, 腫瘤を摘出したとこ 了, 腫瘤内は黄白色充実性で一部膿汁を含み, 長径 $4 \mathrm{~cm}$ の魚骨と思われる異物を認めた(図 3 ). 癒着した横行 結腸の部位に一部腸壁の突出があり, 魚骨の穿通部位 と考えられたが, 瘦孔は確認できなかった. 組織学的 には膿湟の器質化した炎症性腫瘤と診断した。術後は 順調に経過し，第15病日に退院した。

\section{考 察}

異物による消化管穿通はまれであり，䜩下された異 物が消化管を穿通する頻度は $1 \%$ 前後と言われてい る ${ }^{11}$. 特に本邦では食生活上, 魚骨によるものが多く ${ }^{21}$, その術前診断は, 極めて困難とされてきた. しかし

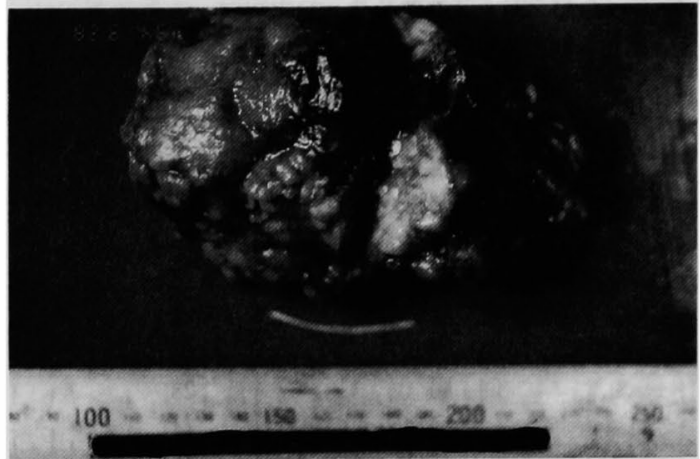

図 3 摘出標本：腫瘤内は黄白色充実性で一部膿汁を 含み, 長径 $4 \mathrm{~cm}$ の魚骨を認めた。

$\mathrm{CT}$, 超音波等, 近年の画像診断の進歩にともない, そ の特徵的な画像所見の描出によって, 従来の急性腹症 という総括的な診断から, 術前に具体的に魚骨の消化 管穿通と診断される症例が増えている3 . 本邦におけ る誤曣魚骨の消化管穿孔・穿通の報告例は，1986年ま での松井らの123例に4)，さらに1994年12月までわれわ れが集計し得た自験例を含む69例を加えて192例で あった，男女比は男性が $72 \%$, 年齢別では40歳〜80歳 代が $66 \%$ と多くしめる.

魚骨誤磺の原因として, 高齢，義歯使用，飲酒等に よる口腔内感覚鈍痳があげられているが5), 今回の集 計では中高年の男性に多く, 飲酒により咀嚼が不十分 なことが一因と考えられた。臨床症状は種々の形で現 われるが, 魚骨が腸管を穿孔して急激に発症し腹膜炎 を起こす場合と, 穿通して緩徐に発現し, 炎症性肉芽 腫を形成する場合があり, 本邦では後者の方が多い6). 集計では, 腹痛 $(62 \%)$, 腹部腫瘤 (36\%), 肛門痛 (16\%), 発熱 (25\%) が 4 大症状であり ${ }^{4)}$, 自験例でも, 肛門痛 以外の 3 症状を認めた. 穿通部位については一定した 報告はないが, 表 1 に示すように, 肛門(29例), 横行 結腸 (26例), S 状結腸（19例）など下部消化管に多い 傾向があり, 固形便の存在が穿通の誘因になるといわ れている4).

また穿通部位をみると回腸穿通例が28例にみられ, 主に回盲部近傍での報告が多く, 回腸末端の Bauhin 弁の存在が魚骨を停滞させるためと思われる。このう ち Meckel 息室穿通例が 4 (例6) 9), 鼠径ヘルニア内の 脱出した腸管穿通例が 1 例 ${ }^{10)}$ 認められ, 腸管の器質的 障害部位に魚骨が停滞した後穿通したと考えられる. しかし消化管壁にまったく所見を認めない穿通部位不 明例も 43 例と多く，これは穿破された腸管壁の防御反 
表 1 魚骨の穿孔・穿通部位

\begin{tabular}{|c|c|}
\hline 部 位 & 例数 \\
\hline 肛 門 & 29 \\
\hline 直 腸 & 8 \\
\hline S 状結腸 & 19 \\
\hline 横行結腸 & 26 \\
\hline 下行結腸 & 6 \\
\hline 盲 腸 & 7 \\
\hline 虫 垂 & 10 \\
\hline 回 腸 & 28 \\
\hline (Meckel の秃室) & (4) \\
\hline (鼠径ヘルニア) & (1) \\
\hline 空 腸 & 4 \\
\hline 十二指腸 & 2 \\
\hline 部位不明小腸 & 2 \\
\hline 胃 & 5 \\
\hline 食道 & 2 \\
\hline 肝 & 1 \\
\hline 不明 & 43 \\
\hline 合 計 & 192 \\
\hline
\end{tabular}

表 2 術前に魚骨が確認された症例

\begin{tabular}{|c|c|c|c|c|}
\hline No & 報告者 & 年柃 & 性 & $\begin{array}{l}\text { 魚骨か確認された } \\
\text { 模直法 }\end{array}$ \\
\hline 1 & 塩野 (1984) & 46 & $\hat{\delta}$ & CT \\
\hline 2 & 小林(1987) & 49 & $\hat{\delta}$ & CT \\
\hline 3 & 岸本 (1987) & 30 & $\delta$ & $A \cdot X \cdot P$ \\
\hline 4 & 野田 (1987) & 不明 & 不明 & US $\mathrm{CT}$ \\
\hline 5 & 青木(1990) & 73 & 古 & CT \\
\hline 6 & 松山(1990) & 75 & 우 & CT \\
\hline 7 & 安東 (1990) & 60 & 우 & CT \\
\hline 8 & 安東 (1990) & 55 & 우 & 直腸診, 門診 \\
\hline 9 & 島岡 (1991) & 40 & $\hat{o}$ & CT \\
\hline 10 & 吉田(1992) & 66 & $\hat{o}$ & CT \\
\hline 11 & 三村 (1993) & 75 & $\hat{o}$ & $\mathrm{CT}$ \\
\hline
\end{tabular}

応により，腸管壁は短期間に修復されるためと言われ ている゙1)。自験例でも腫瘤に庱着した横行結腸に一部 腸壁の突出が認められ魚骨の穿通部位と考えられた

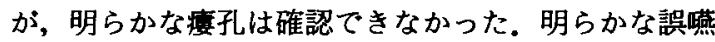
の既往があり，誤䁵して間もない場合では術前の診断 が可能であるが，多くの場合は本症を疑うことは困難 とされてきた．今回の集計でも悪性腫瘍 (27例)，原因 不明の炎症性腫瘤 (27例)，急性虫垂炎 (21例)，その 他原因不明の急性腹症 (21例) として手術されており， 特に術前に悪性腫瘍と診断された症例の中にはリンパ 節郭清等の過大侵睡の手術を施行した例も見られ $3^{12)}$. 1994年12月までの自験例を含めた192例中術前に 診断しえたのは11（5.3\%）例に過ぎず(表 2$)^{14) \sim 23), ~}$
さらに術後 retrospective に診断しえた例も26例のみ であった．魚骨による消化管穿通の画像上の特徴をを みると注腸所見は腸管の長短軸両方向の進展不良像, 超音波所見は腫瘤内の直線状の hyperechoic area, CT 所見は腫溜内の直線状の high density area であ る. そのうち1978年に草島らは注腸造影にて，その炎 症性狭窄や蛇腹状腸管短縮像などの腸管の長短軸両方 向への進展不良像が異物性炎症性肉芽腫に特街的な所 見であるとし，術後 retrospective に診断しえた症例 として報告している13).

しかし術前もしくは術後 retrospectiveに診断しえ た症例のほとんどが1980年以降に報告されたものであ り，これは CT・超音波の普及にともない，少ない侵襲 でその特徴的な画像所見が描出できるようになったた めであると考えられる．これらの症例に共通する超音 波·CT 所見は，腫瘦内に魚骨と思われる直線状の石灰 化陰影が描出されたことであり，鑑別診断を要する他 の炎症性疾患や，悪性腫瘍では認め得ない特徴的所見 と思われる。自験例においても術後 retrospectiveに に検討したところ同様の所見が認められた。しかし自 験例も含めて, 術前の超音波・CT 等て魚骨陰影が描出 されているが本症を念頭においいていなかったため，術 後 retrospectiveに診断しえた症例と報告されるもの が多いのが現状である．術前診断が正確にされていな い例が多く，原因不明の炎症性腫瘤では本症も念頭に おいて診断する必要があると考えられた。

結語

魚骨の消化管穿通による腹腔内腫瘤の 1 例を報告し た．魚骨誤㙹による消化管穿孔・穿通の診断には超音 波・CT が有用で，原因不明の腹部腫瘤や急性腹症の症 例には本症も念頭において精査する必要がある.

\section{文献}

1) McPherson RC, et al: Forein body perforation of the intestinal tract. Am J Surg $94: 564-566$, 1957

2）大倉正二郎：腹腔内異物について。外科 21 : 1141,1959

3）堀 堅造，東 龍男，金只堅治他：魚骨穿孔，別冊 日本臨彇, 領域別症候群 6 消化管症候群下巻, 1994, p157-159

4）松井昭彦，岡島邦雄，川西瑞穂他：魚骨による消化 管穿孔の 2 治験例。日臨外医会誌 47:955-961, 1986

5）高野久煇，吉岡暲二，侢 三郎他：誤䁒魚骨片の腸 管穿通による腹部腫㿔の 3 例. 外科治療 $23: 235$ $-238,1970$ 
6）大田正隆, 富川一朗, 田中 誠他：魚骨によるメッ ケル䕀室穿孔の 1 症例。三重医 26:90-91, 1982

7）木村慶子, 鎌田国尋, 金森裕他：異物による Meckel 憩室穿孔の 1 症例. 道南医会誌 25 : 9598, 1990

8）佐々木一晃, 中野昌志, 田中 実他: 腹膜炎を呈し た誤睘魚骨による Meckel 㕷室穿通の 1 治験例。 外科 $55: 455-456,1993$

9）田中 満, 宇都宮裕文, 松谷泰男他：魚骨による Meckel 頽室穿孔の 1 例. 日消外会誌 $25: 1325-$ 1328, 1992

10）中尾達也, 佐々木晨, 川口正晴他: 嵌頓鼠径へル二 ア手術の際偶然発見された魚ほねの腸管穿通によ る汎発生腹膜炎の例。広島医 $43 ： 1569-1571$, 1990

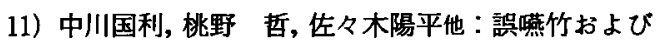
魚骨による腹腔内朖場の 3 例. 腹部画像診断 8 : $330-333,1988$

12）内田隆寿, 藤原 隆, 光吉 貢他：魚骨による腹腔 内消化管穿孔・穿通の 4 症例の検討. 腹部画像診断 $13: 137-145,1993$

13）草島義徳, 宮崎逸夫, 尾島敏夫他：誤睘魚骨による 結腸異物性肉芽腫 2 例の検討. 臨外 $33: 1489$ 1492,1978

14）塩野 茂, 金城守人, 平良博史他：魚骨により小腸 穿孔をきたし,腹腔内膘癔を形成した 1 治験例. 沖 綶医会誌 $21: 321-322,1984$
15）小林達則，松田忠和，良井㳯哲他：CTによって診 断した魚骨穿孔による回盲部異物性肉芽の 1 例. 外科診療 $29: 396-400,1987$

16）岸本幸広，高城英俊，賀戸和男他：術前の腹単にて 魚骨が指摘できた魚骨による盲腸穿孔の1例，日 消病会誌 $84: 2427,1987$

17）野田康永,三重野寛治, 大瀧 和他：術前診断し得 た魚骨による消化管穿通の 1 自験例。日消病会誌 $84: 2427,1987$

18）青木 茂, 神武 裕, 坂本 力：異物(魚骨)穿通に よるものと思われる肝膿瘍. 日独医報 $35: 322 一$ 323,1990

19）松山敏哉, 市場康之, 岡島正純他：魚骨による直腸 周囲脹瘍の 1 例. 広島医 $43: 589-590,1990$

20）安東俊明, 恩田昌彦, 森山雄吉他：誤德魚骨による 消化管穿孔・穿通の 3 例. 日消外会誌 $23: 889$ 893,1990

21）島岡俊治, 矢野武誌, 溝内十朗他：術前に CTにて 診断し得た魚骨による腹腔内膿瘍の 1 例。日医師 会誌 $50: 219,1991$

22）吉田栄一, 藤澤憲司, 山田隆年他：CT にて診断さ れた魚骨穿通による腹壁腫瘤の 1 例. 日臨外医会 誌 $53: 351,1992$

23）三村卓司, 難波康男, 森岡 徹他：CTにて診断し えた魚骨疝痛による腹腔内腿瘍の 1 例. 広島医 $46: 15-18,1993$

\title{
INTRAABDOMINAL TUMOR DUE TO INTESTINAL PERFORATION OF A FISH BONE
}

\author{
Noriomi HOSAKA, Akira SUGITA, Shingo FUKAZAWA, Yasuhiro KOIZUMI, \\ Konosuke KIUCHI and Tadakazu NAKA \\ Department of Surgery, National Yokohama Hospital
}

A 48-year-old man visited another hospital because of an abdominal pain after meals lasting for one month and an abdominal tumor which was noticed recently. Abdominal $\mathrm{CT}$ revealed an intraabdominal tumor. The patient was admitted to the hospital for exploration. On admission an elastic hard tumor 8 $\mathrm{cm}$ in diameter with tenderness and smooth surface was plapated on the left side of the navel. On blood chemical analysis increases in leukocytes and CRP were noted. Abdominal CT and ultrasonography visualized a protruding tumor into the abdominal cavity which was internally heterogenous and associated with linear calcification in the lumen. Laparotomy was performed with a diagnosis of intraabdominal inflammatory tumor. The tumor strongly adhered to the transverse colon, was covered with the greater omentum, and was adjacent to the peritoneum beneath the left rectus abdominits muscle. The excised tumor was yellowish-white in color and solid involving pus partially and a foreign body which was probably a fish bone with a longer diameter of $4 \mathrm{~cm}$ was confirmed. In this case, it was thought that the fish bone perforated the transverse colon and formed an abscess in the abdominal cavity. When intraab. dominal tumors of unknown origin are encountered, a possibility of perforation of some intestinal foreign body should be entertained in the diagnosis and treatment. 